\title{
ПОГРЕБАЛЬНЫЙ КОМПЛЕКС ЭПОХИ БРОНЗЫ УРОЧИЩА ТЕСИК
}

\section{(C) 2021 г. Александр Анатольевич Горячев ${ }^{1}$, Станислав Александрович Потапов ${ }^{1}$, Михаил Алексеевич Чернов ${ }^{1}$}

\author{
${ }^{1}$ старший научный сотрудник, Институт археологии им. А.Х. Маргулана, \\ г. Алматы, Казахстан. E-mail: aga.2805@mail.ru \\ ${ }^{1}$ научный сотрудник, Институт археологии им. А.Х. Маргулана, \\ г. Алматы, Казахстан. E-mail: potapov-stas@yandex.ru \\ ${ }^{1}$ специалист-художник, Институт археологии им. А.Х. Маргулана, \\ г. Алматы, Казахстан. E-mail: mihalapych@yandex.kz
}

\begin{abstract}
Аннотация. В статье систематизированы результаты исследований погребального комплекса могильника эпохи бронзы Тесик-І одноименного урочища в горах Айтау. Комплекс состоит из 56 разнотипных и разновременных в пределах эпохи бронзы сооружений в виде курганов и оград прямоугольной, квадратной и округлой форм. Основные виды погребальных камер представлены каменными ящиками и цистами. Исследования погребального комплекса эпохи бронзы урочища Тесик производились на основе выработанных ранее для региона методов археологической разведки и раскопок.

В центральный части могильника Тесик-I исследована конструкция цепочки каменных оград размерами $~ 14 \times 5,8$ м, где расчищено шесть погребальных сооружений в виде каменных ящиков. Все крупные могильные конструкции по характеру и форме сооружения напоминают «бесик», что, вероятно, связано с религиозными представлениями древнего населения о Смерти как акте перерождения в ином загробном мире. Умерших хоронили в скорченном виде на левом боку головой на запад. Как правило в изголовье устанавливалась керамическая посуда (от одного до трех сосудов). Вещевой инвентарь (изделия из глины и бронзы), фиксируемые среди костных останков внутри могил, являлись деталями и украшениями погребальной одежды и маркировали их социальный статус. К особенностям погребальной практики всех захоронений комплекса следует отнести помещение в могилу «порченной» посуды.
\end{abstract}

Исследованный комплекс, датируемый в пределах XVI-XV вв. до н.э., представляет смешанные алакульско-федоровские погребальные традиции андроновского периода эпохи бронзы Шу-Илейского региона. Развитие древней культуры во взаимодействии с населением Центрального Казахстана сформировало круг погребальных комплексов Шу-Илейского междуречья, имеющих существенные отличия от памятников других районов Жетысу в горах Джунгарского (Жетысу) и Заилийского (Иле) Алатау. Перспектива дальнейших исследований связана с изучением всей структуры погребальных комплексов Шу-Илейского междуречья и степени

Работа выполнена при финансовой поддержке Комитета науки Министерства образования и науки Республики Казахстан 
социально-экономических и этнокультурных взаимосвязей древнего населения с соседними регионами.

Ключевые слова: археология, Жетысу, Шу-Илейские горы, урочище Тесик, эпоха бронзы, археологический комплекс, могильник, петроглифы, погребальные традиции, керамика, вещевой инвентарь

\title{
ТЕСІК ШАТҚАЛЫНДАҒЫ КОЛА ДӘУІРІНІН ЖЕРЛЕУ КЕШЕНІ
}

\section{Александр Анатольевич Горячев ${ }^{1}$, Станислав Александрович Потапов ${ }^{1}$, Михаил Алексеевич Чернов ${ }^{1}$}

\author{
${ }^{1}$ аға ғылыми қызметкер, Ә.Х. Марғұлан атындағы Археология институты, \\ Алматы қ., Қазақстан. E-mail: aga.2805@mail.ru \\ ${ }^{1}$ ғылыми қызметкер, Ә.Х. Марғұлан атындағы Археология институты, \\ Алматы қ., Қазақстан. E-mail: potapov-stas@yandex.ru \\ ${ }^{1}$ маман-суретші, Ә.Х. Марғұлан атындағы Археология институты, \\ Алматы қ., Қазақстан. E-mail: mihalapych@yandex.kz
}

\begin{abstract}
Аннотация. Мақалада Айтау тауындағы шатқалмен аттас Тесік-I қола дәуірі қорымының жерлеу кешенін зерттеу нәтижелері жүйеленген. Кешен қола дәуіріндегі 56 әр түрлі және әр уақыттағы төртбұрышты, тік төртбұрышты және домалақ пішіндегі қорған және қоршау түріндегі құрылыстардан тұрады. Жерлеу камераларының негізгі түрі тас жәшік пен цисталармен көрсетілген. Тесік шатқалының қола дәуіріндегі жерлеу кешенін зерттеу бұған дейін өңірдегі қалыптасқан археологиялық барлау мен қазба жұмыстары әдістері негізінде жүргізілді.

Тесік-І қорымының орталық бөлігінде көлемі 14×5,8 м тас қоршаулар тізбегінің құрылысы зерттелді, онда тас жәшіктер түріндегі алты жерлеу құрылысы тазартылды. Құрылыстың сипаты мен формасындағы барлық ірі қабір құрылымдары «бесікке» ұқсайды, бұл ежелгі тұрғындардың өлім туралы діни идеяларымен басқа әлемде қайта туылу актісі ретінде байланысты болуы мүмкін. Қайтыс болғандарды, бүктелген түрде сол жағымен басын батысқа қаратып жерледі. Керамикалық ыдыстар (бір ыдыстан үш ыдысқа дейін) бас жағына қойылды. Қабір ішіндегі сүйек қалдықтарының арасынан алынған заттар (саздан және қоладан жасалған бұйымдар) жерлеу киімдерінің бөлшектері мен әшекейлері болып табылады және олардың әлеуметтік мәртебесін белгілейді. Кешеннің барлық жерлеулерінің жерлеу тәжірибесінің ерекшеліктеріне қабірге «бүлінген» ыдыс-аяқтың орналастырылуын жатқызуға болады.

Зерттелген кешен біздің дәуірімізге дейінгі XVI-XV ғасырлар аралығындағы Шу-Іле аймағының қола дәуірінің андронов кезеңіндегі ежелгі тұрғындарының аралас Алакөл-Федоров жерлеу дәстүрлерін көрсетеді. Орталық Қазақстан халқымен қарқынды байланыстар Жетісу және Іле Алатауы тауларындағы Жетісудың басқа аудандарының ежелгі қорымдарынан айтарлықтай айырмашылықтары бар Шу-Іле өзендері аралығындағы жерлеу кешендерінің шеңберін бөліп көрсетуге мүмкіндік береді. Ары қарай зерттеулердің мақсаты Шу-Іле өзендері аралығындағы жерлеу кешендерінің бүкіл құрылымын және ежелгі тұрғындардың көрші аймақтармен өзара әлеуметтік-экономикалық және этномәдени байланысының дәрежесін зерттеумен байланысты.
\end{abstract}

Түйін сөздер: археология, Жетысу, Шу-Іле таулары, Тесік шатқалы, қола дәуірі, археологиялық кешен, қорым, петроглифтер, жерлеу дәстүрлері, қыш, заттай құралжабдықтар 
Горячев А.А., Потапов С.А., Чернов М.A. Погребальный комплекс эпохи бронзы ...

\title{
FUNERAL COMPLEX OF BRONZE AGE OF THE TESIK TRACT
}

\section{Alexander A. Goryachev ${ }^{1}$, Stanislav A. Potapov ${ }^{1}$, Mikhail. A. Chernov ${ }^{1}$}

${ }^{1}$ Senior scientific researcher, A.Kh. Margulan Archeology Institute, Almaty, Kazakhstan. E-mail: aga.2805@mail.ru

${ }^{1}$ Scientific researcher, A.Kh. Margulan Archeology Institute, Almaty, Kazakhstan. E-mail: potapov-stas@yandex.ru ${ }^{1}$ Specialist draftsman, A.Kh.Margulan Archeology Institute, Almaty, Kazakhstan. E-mail: mihalapych@yandex.kz

\begin{abstract}
The article systematizes the results of the research of the funeral complex of the burial ground of the Bronze Age Tesik-1 in the Aitau mountains. The complex consists of 56 structures of different types and at different times within the Bronze Age in the form of mounds and fences of rectangular, square and rounded forms. The main types of burial chambers are represented by stone boxes and cists. Investigations of the burial complex of the Bronze Age of the Tesik tract were carried out on the basis of previously developed for the region methods of archaeological exploration and excavation.

In the central part of the Tesik-1 burial ground the construction of a chain of stone fences, measuring $\sim 14 \times 5.8 \mathrm{~m}$, where 6 funerary structures in the form of stone boxes were excavated, was investigated. All large grave constructions resemble "besik" in character and form that probably was connected with religious representations of the ancient population about Death as an act of rebirth in other afterlife. The dead were buried on the left side of the body with the head to the west. As a rule, ceramic dishes (one to three vessels) were placed in the headboard. Clay and bronze articles fixed among the bone remains inside the graves were parts and ornaments of the burial clothes and marked their social status. The peculiarities of the burial practices of all the burials of the complex include the placement of "spoiled" utensils into the grave.

The studied complex, dated within $16^{\text {th }}-15^{\text {th }}$ centuries BC, represents the mixed AlakulFedorovo burial traditions of the ancient population of the Andronovo period of the Bronze Age in the Shu-Ile region. Intensive contacts with the population of Central Kazakhstan allow us to identify a range of burial complexes of the Shu-Ile interfluve that have significant differences from the ancient burial grounds of other regions of Jetysu in the Jungar (Jetysu) and Zailiyskiy (Ile) Alatau mountains. The prospect of further research is associated with the study of the whole structure of the burial complexes of the Shu-Ile interfluve and the degree of socio-economic and ethno cultural interrelations of the ancient population with the neighboring regions.
\end{abstract}

Keywords: archaeology, Jetysu, Shu-Ile mountains, Tesik gorge, Bronze Age, archaeological complex, burial, petroglyphs, funeral traditions, ceramics, clothing materials

\section{Введение}

В полевом сезоне 2020 г. археологические исследования проводились в урочище Тесик северных склонов гор Айтау, где был зафиксирован археологический комплекс из поселения, наиболее крупного в микрорайоне могильника эпохи бронзы Тесик-I и скопления древних наскальных рисунков (рис. 1,1$)$. Поселение бронзо- вого века было устроено в срединной части по северному борту урочища У выходов родников. В дальнейшем этот участок являлся постоянным местом проживания людей в древности и средневековье вплоть до наших дней. Могильник расположен в 1,5 км к западу от поселения в центральной части урочища Тесик, представляющего собой широкую равнину с уклоном в 

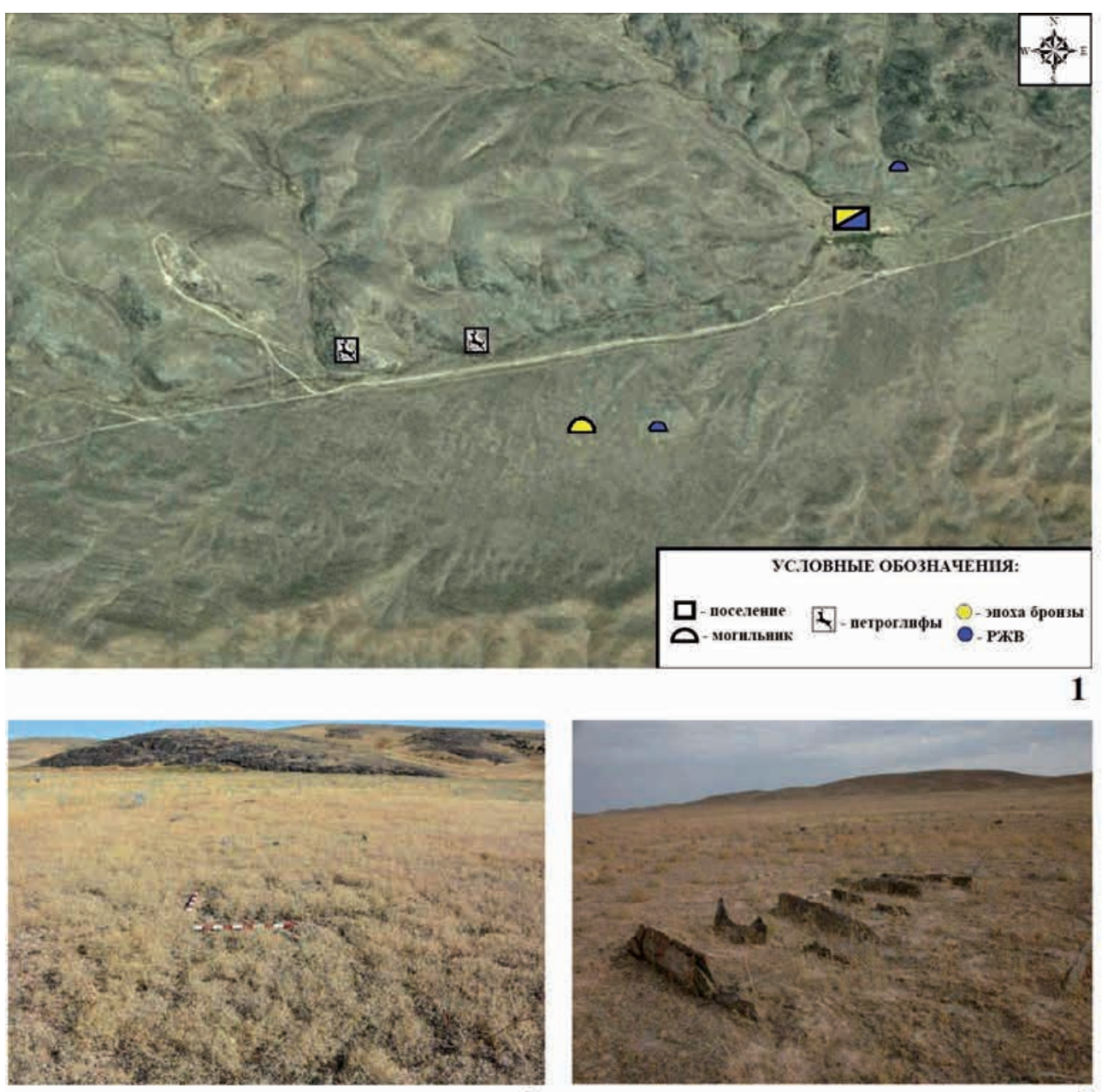

2
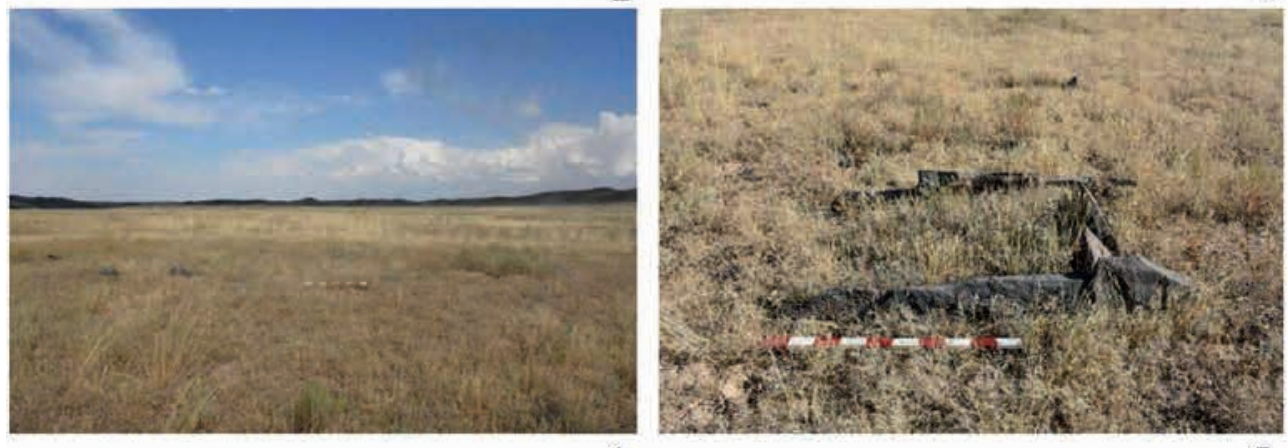

Рис. 1. Древний археологический комплекс урочища Тесик:

1 - расположение древних памятников на космоснимке;

2 -мог. эпохи бронзы Тесик-I, вид на север;

3-5 - погребальные конструкичии эпохи бронзы мог. Тесик-І. Фото авторов

Fig. 1. Ancient archaeological complex of the Tesik tract:

1 - location of ancient monuments on the satellite image;

2 - Tesik-I Bronze Age burial ground, view to the north;

3-5 - Bronze Age burial structures of the Tesik-I burial ground. Authors's photo 
Горячев А.А., Потапов С.А., Чернов М.А. Погребальный комплекс эпохи бронзы ...

северо-западном направлении. Крупное скопление древнейших петроглифов обнаружено на сопке к северу от могильника Тесик-I (рис. 1, 2). Основная их часть представляет собой невыразительные рисунки с изображением животных - козлов, архаров, быков, лошадей, верблюдов и достаточно примитивные антропоморфные фигуры. Среди композиций эпохи бронзы преобладают сцены охоты, выпаса скота, выделяется несколько сцен с изображением людей в ритуальных позах и солярными символами.

Могильник определяется по выступающим каменным конструкциям оград и погребальных камер в виде каменных ящиков и состоит из 56 отдельных погребальных сооружений и цепочек оград, расположенных компактно, но отдельно друг от друга (рис. 1, 2-5). Конструкции отличаются как по форме, так и по структурной организации. Среди них выделяется серия курганов с одиночными или парными захоронениями по центру, устроенных в северной и западной части погребального комплекса. Отмечены как прямоугольные, так и квадратные ограды с каменными ящиками внутри от одного до трех. Округлые ограды с погребальными камерами в виде цист встречены только в восточной части могильника. Археологические раскопки 2020 г. позволили провести их культурно-хронологическую атрибуцию на основе реконструкции традиций погребальной обрядности в центральной части комплекса.

\section{Методика исследований}

Определение структуры археологического комплекса эпохи бронзы урочища Тесик производилось на основе методов археологической разведки, которая включала в себя сбор и анализ имеющихся архивных и библиографических материалов, топографических карт, дешифровки космических снимков региона, натурного обследования объектов и камеральной обработки полученных результатов и их систематизацию. Данный алгоритм был разработан для настоящего микрорайона в ходе предыдущих исследований Хантауского научного отряда [Воякин и др., 2020, с. 91-98].

Практические исследования погребальных объектов могильника Тесик-I проведены согласно методики археологических раскопок с последующей камеральной обработкой полученных материалов. Металлический инвентарь и керамическая посуда подвергнуты предварительному анализу технологий их производства и применения, что позволило расширить возможности реконструкции традиций погребальной обрядности древнего населения региона.

Теоретические исследования материалов исследований погребального комплекса урочища Тесик производились на основе их систематизации с последующей реконструкцией погребально-поминальных традиций эпохи бронзы данного микрорайона и сравнительного анализа полученных результатов с материалами других районов Шу-Илейского междуречья. В результате выявлено положение погребального комплекса среди других археологических памятников бронзового века региона. Культурнохронологическая атрибуция комплекса выяснена в результате сопоставления его данных с погребальными памятниками сопредельных регионов Жетысу, Центрального и Южного Казахстана. Это позволило определить положение памятника в структуре 
историко-культурного развития древних племен эпохи бронзы Казахстана.

Описание материалов исследований могильника Тесик-I

В 2020 г. раскоп размерами $12 \times 8$ м, ориентированный по оси С-Ю, был заложен по периметру конструкции цепочки каменных оград в центральной части могильника, расположенной на возвышенности (40$50 \mathrm{cm)} \mathrm{относительно} \mathrm{ровного} \mathrm{участка}$ (рис. 2). С целью полного охвата погребальных конструкций к нему сделаны две прирезки: с юга размерами $4 \times 0,5$ м и с западной стороны $2 \times 1$ м. Общая площадь его составила $100 \mathrm{~m}^{2}$. В результате открыты шесть погребальных сооружений в каменных оградах, сложенных крупных камен- ных плит, вкопанных на ребро и уложенных плашмя в 1-3 слоя. Общие размеры сооружения определялись в пределах $\sim 14 \times 5,8$ м.

Конструкция состоит из четыpex каменных оград прямоугольной формы, устроенных в цепочку, ориентированную по оси С-Ю. Они были сложены из крупных каменных плит (до 1,5 м в длину), вкопанных вертикально на глубину до 20 см и выступающих над поверхностью на 30-50 см. Размеры оград, ориентированных по оси 3-В составляют: 5,8 $\times 4,5$ м, $5,8 \times 5$ м, $5,8 \times 2,2$ м и $5 \times 3$ м. Все каменные стенки с южной и северной сторон являются смежными, что позволяет считать начало сооружения цепочки с северной стороны с последующим продолжением в южном направлении.
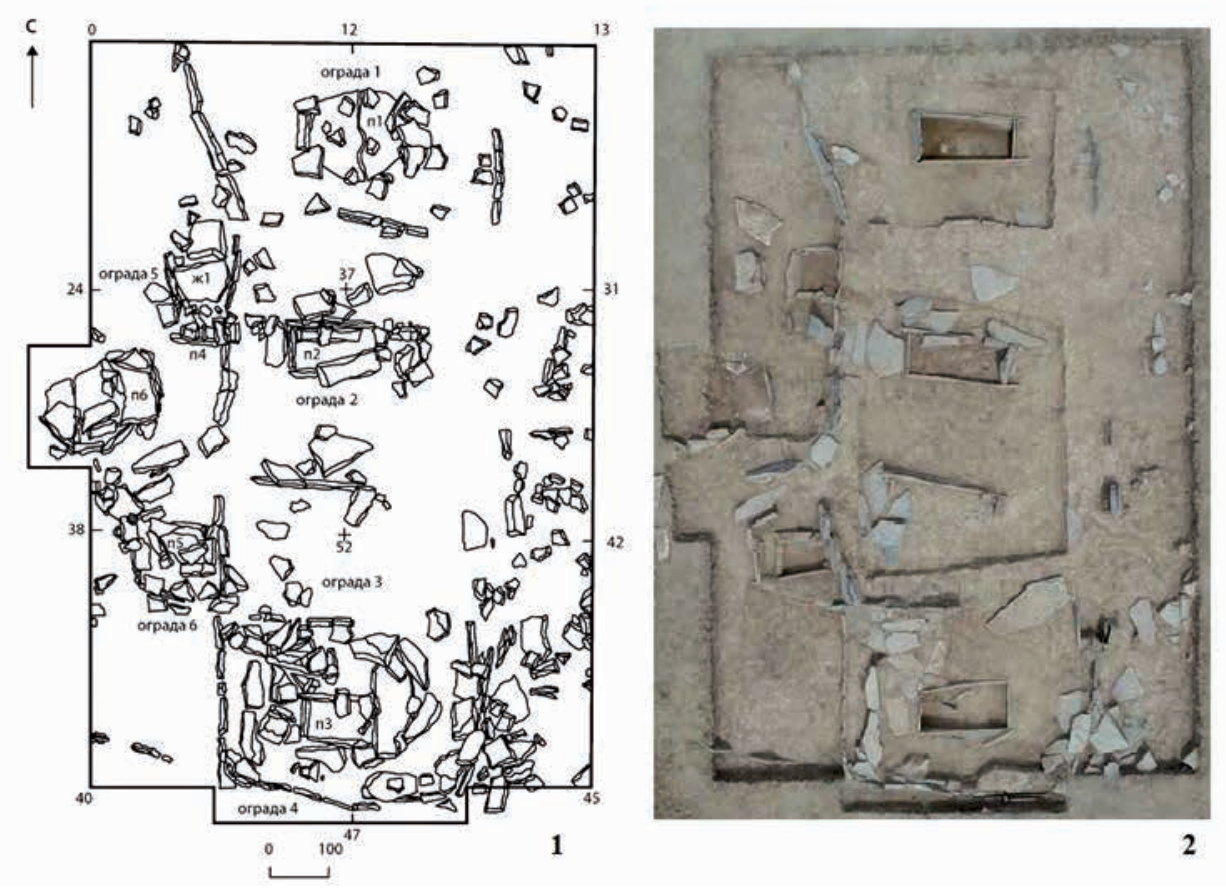

Рис. 2. Тесик-I, конструкиия 1: 1 - план раскопа; 2 -аэрофото

Fig. 2. Tesik-I, construction 1: 1 - excavation plan; 2 -aerial photo 
Горячев А.А., Потапов С.А., Чернов М.А. Погребальный комплекс эпохи бронзы ...

Боковые пристройки с подзахоронениями детей и взрослых устроены с западной стороны основной цепочки оград. Часть каменных конструкций зафиксирована в полуразрушенном состоянии.

Погребение 1 расположено в центральной части ограды 1 и представляло собой каменный ящик 2,1×1,3 м, перекрытый сверху двумя массивными каменными плитами поперек могилы. Размеры плит - $130 \times 85$ см и $130 \times 70$ см (рис. 2, 1). Помимо них по периметру стенок могилы были уложены небольшие каменные плитки, а вдоль северной, восточной и южной стенок - в западной части врыты на ребро плитыподпорки длиной от 30 до 150 см. Размеры погребения по дну составили $180 \times 80$ см. Форма погребальной камеры напоминает «бесик», так как западная и восточная стенки выше северной и южной на 20-30 см и ниже дна могилы на 10 см (рис. 3, 1).

В заполнении могильной ямы (рыхлая супесь) на дне 70 (85) см зафиксировано захоронение взрослого индивидуума средних лет в скорченном виде на боку, головой на запад (рис. 3,2 ). В районе черепа обнаружены бронзовые подвески в 1,75 оборота, плакированные золотой фольгой (рис. 3,7$)$. Той же технологией выполнена бронзовая бляшка, найденная под нижней челюстью (рис. 3, 6). В районе рук отмечены фрагменты двух бронзовых браслетов и бус. В этой же части могилы найдена серия пастовых бус, фрагмент бронзового накосника и четыре нашивные бляшки листовидной формы. Возле костей ног в районе щиколоток найдены бронзовые бусы (рис. 3, 8-13). Кости ног сильно окрашены в результате коррозии бронзовых изделий. В изголовье погребенного у западной стенки было установлено три керамических сосуда: два крупных горшковидных сосуда с геометрическим орнаментом и без, а также небольшой баночный сосуд (рис. 3, 3-5). Два последних были накрыты каменными плитками.

С юго-западной стороны ограды 1 обнаружена конструкция из каменных плит подквадратной формы (Ж1), размерами $1,8 \times 1,8$ м, в центре которой найден керамический сосуд на дне ямы глубиной 40 см (рис. 4). У юго-западного угла ограды 1 в ограде 5 квадратной формы размерами $70 \times 70$ см обнаружено погребение 4 в виде каменного ящика, размерами $70 \times 50$ см и глубиной 40 см, перекрытого плитой и наброской из камней мелких и средних размеров. На глубине 30 см в северо-западном углу найдена каменная плитка, которыми обычно перекрывают керамическую посуду. Однако, ни сосуда, ни костных останков погребенного не обнаружено.

Погребение 2 в виде каменного ящика $(1,55 \times 0,70$ м) расположено в центральной части ограды 2. Первоначально оно перекрывалось сверху двумя массивными каменными плитами поперек могилы, которые были разрушены (рис. 5, 1, 2). По периметру стенок могилы уложены и врыты небольшие каменные плиты-подпорки (30-80 см). В заполнении могильной ямы (плотноспрессованная супесь) фиксировались фрагменты каменных конструкций могилы, костей скелета погребенного, керамики, бронзовых изделий и пастовых бус (рис. 5, 3-11). Форма погребальной камеры также напоминает «бесик», так как западная и восточная стенки выше северной и южной на 20-30 см и ниже дна могилы на 10 см. На дне вследствие тща- 


\section{ҚАЗАҚСТАН АРХЕОЛОГИЯСЫ № 1 (11) 2021}

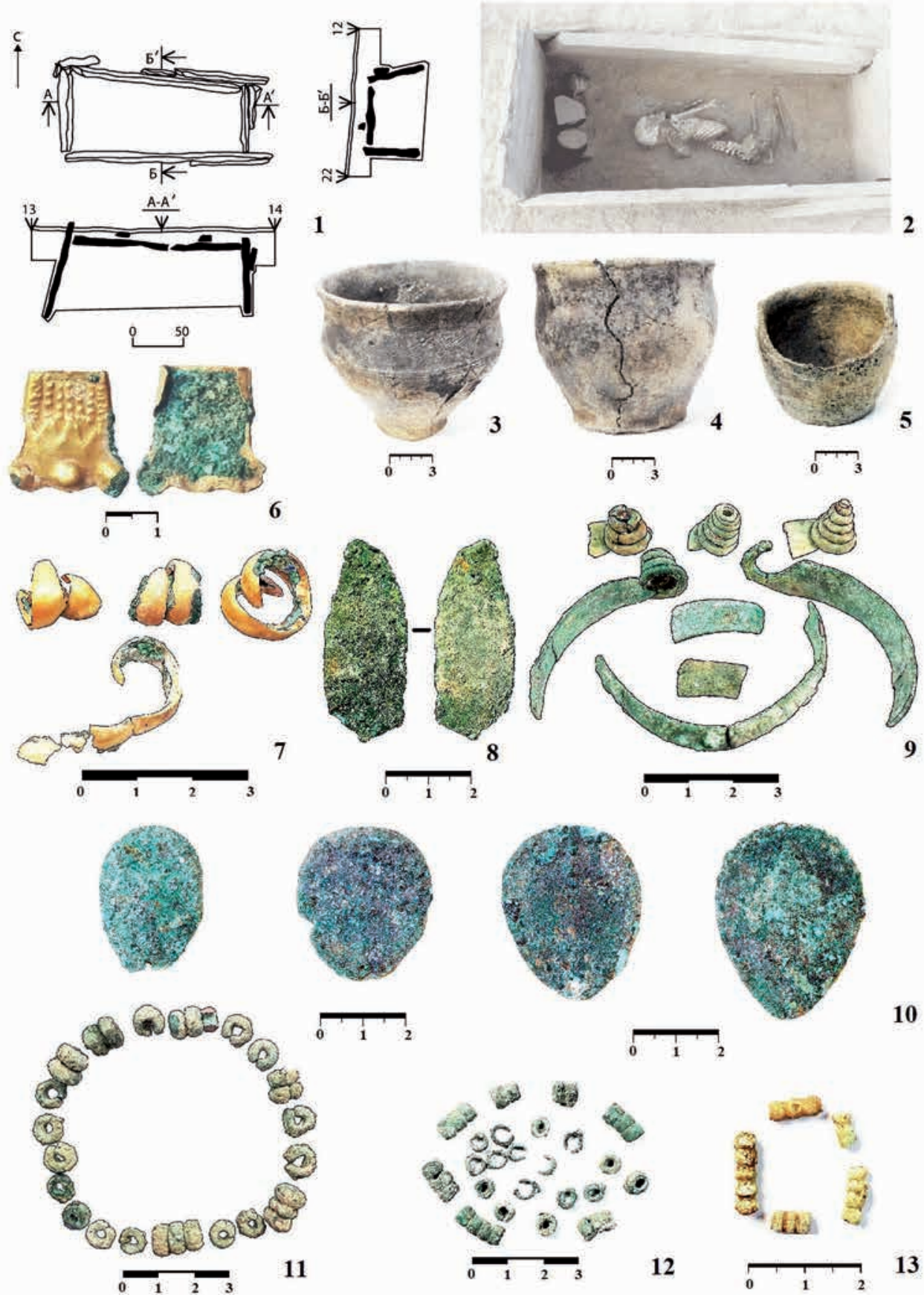

Рис. 3. Тесик-I, ограда 1, n. 1: 1 - план и разрезы погребальной камеры;

2 - фото захоронения; 3-5-керамическая посуда; 6, 7 - бронзовые украшения, плакированные золотой фольгой; 8-12 - бронзовые изделия;

13 - пастовые (глиняные) бусы

Fig. 3. Tesik-I, fence 1, burials 1: 1-plan and sections of the burial chamber;

2 - photo of the burial; 3-5-ceramic dishes; 6, 7 -bronze jewelry clad with gold foil; 8-12 - bronze products; 13 - paste (clay) beads 
Горячев А.А., Потапов С.А., Чернов М.А. Погребальный комплекс эпохи бронзы ...
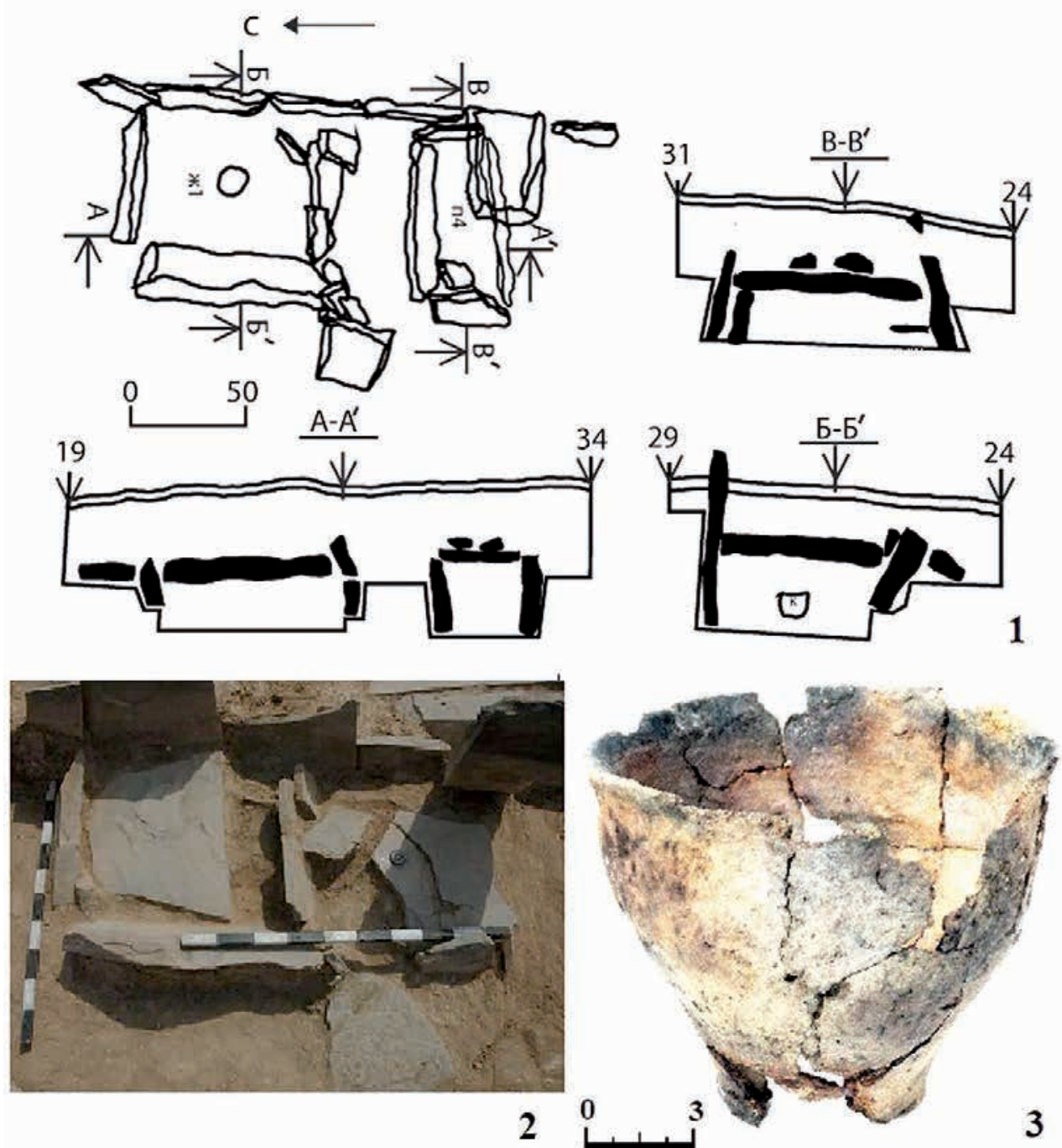

Рис. 4. Тесик-I. Погребально-поминальные конструкичи, пристроенные с юго-западной стороны ограды 1: 1 - план и разрезы жертвенника (Ж1) и n. 4 в ограде 5;

2 - фото конструкиии жертвенника и п. 4 до расчистки; 3 - керамический сосуд из жертвенника (Ж1)

Fig. 4. Tesik-I. Funeral and memorial structures attached to the south-western side of the fence 1: 1-plan and sections of the altar (A1) and item 4 in the fence 5;

2 - photo of the altar structure and item 4 before clearing;

3 - ceramic vessel from the altar (A1)

тельного ограбления могилы вещевого материала и сколь-нибудь значимых фрагментов костей погребенного не обнаружено (рис. 5, 2).
Внутри ограды 3 погребальной камеры не зафиксировано, что дает основание предполагать ее сооружение с расчетом на будущее захоро- 


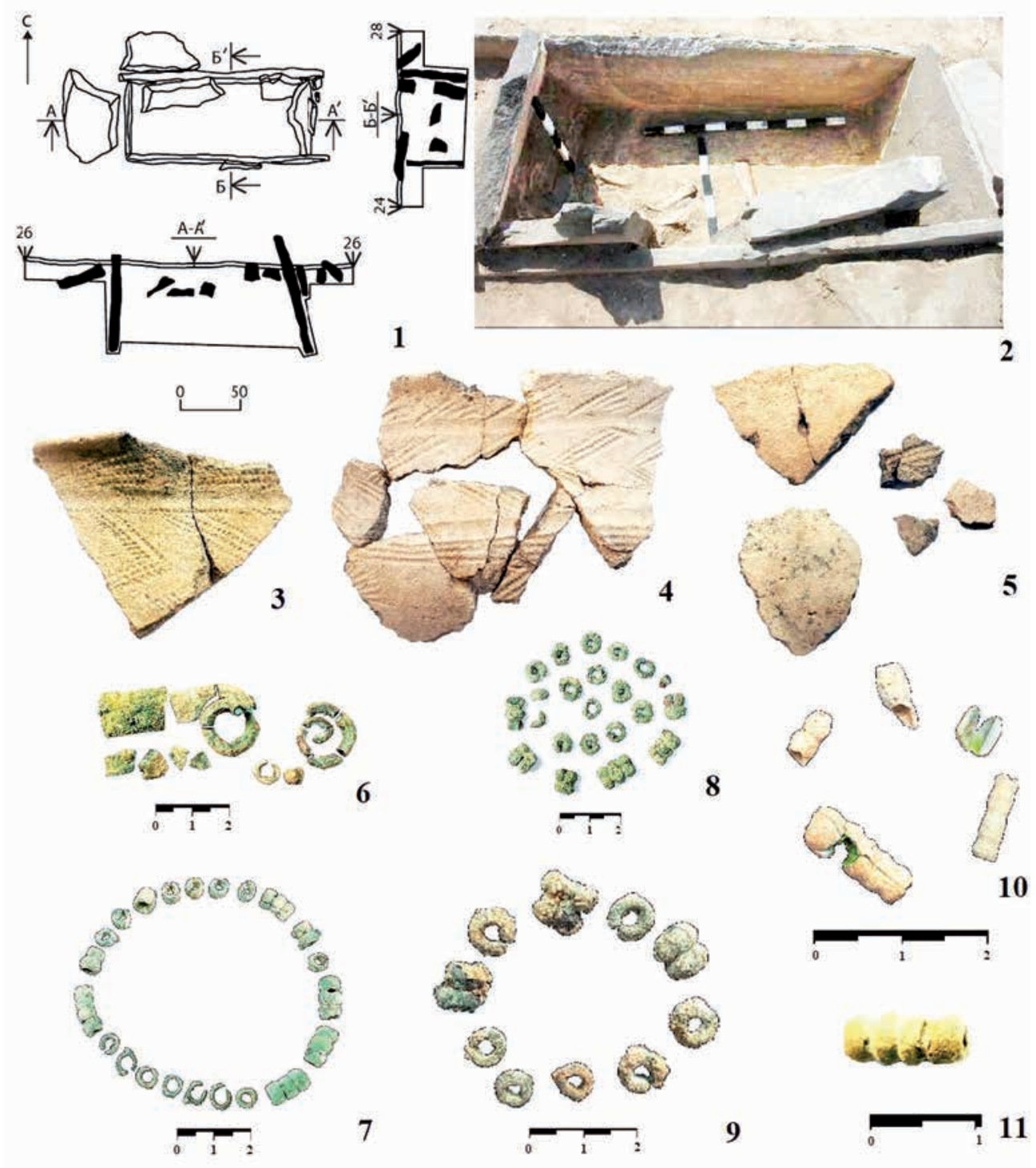

Рис. 5. Тесик-I, ограда 2, п. 2: 1 - план и разрезы погребальной камеры; 2- фото могиль; 3-5-керамика; 6-9-бронзовые изделия; 10, 11 - пастовые (глиняные) бусы

Fig. 5. Tesik-I, fence 2, burial 2: 1-plan and sections of the burial chamber; 2 - photo of the grave; 3-5-ceramics; 6-9-bronze products; 10, 11-paste (clay) beads

нение, которое в итоге не состоялось (рис. 2, 2). С западной стороны ограды в пристройке квадратной формы (ограда 6), размерами $1,6 \times 1,6$ м за- фиксировано детское подзахоронение в погребении 5. Оно представляло собой каменный ящик $(80 \times 55$ см) с верхней крупной плитой перекрытия вдоль 
Горячев А.А., Потапов С.А., Чернов М.А. Погребальный комплекс эпохи бронзы ...

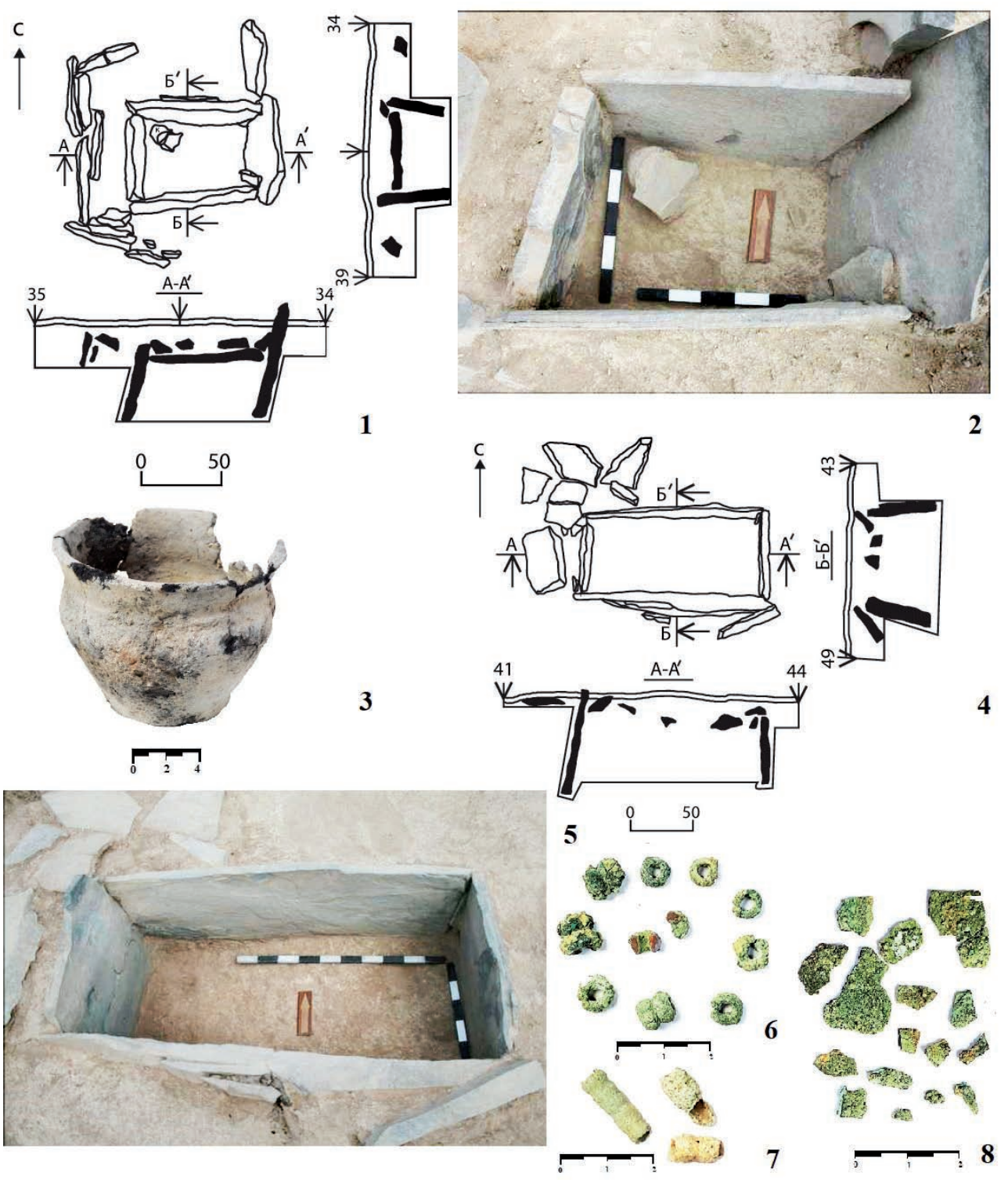

Рис. 6. Тесик-I. Погребальные сооружения в южной части конструкичи 1:

1 - план и разрезы погребальной камеры 5; 2 - фото могиль 5 в ограде 6;

3 - керамический сосуд из n. 5; 4 -план и разрезы погребальной камеры 3 в ограде 4;

5 - фото могильл 3 в ограде 4; 6, 8-фрагменты бронзовых изделий из n. 3; 7 - пастовые (глиняные) бусыл из $n .3$

Fig. 6. Tesik-I. Burial structures in the southern part of structure 1:

1 -plan and sections of burial chambers 5; 2 -photo of grave 5 in the wall 6;

3 - ceramic vessels from burial 5; 4-plan and sections of the burial chamber 3 in the wall 4;

5 -photo of grave 3 in the wall 4; 6, 8-fragments of bronze objects from burial 3; 7 - paste (clay) beads from burial 3 
могилы, закрытой сверху наброской из камней мелких и средних размеров. На дне (50 см) в северо-западном углу обнаружен керамический сосуд, накрытый каменной плиткой. Костные останки погребённого ребенка не сохранились (рис. 6, 1-3).

Погребение 3 - каменный ящик $(1,6 \times 1$ м) - расположено в центральной части ограды 4. Плиты перекрытия над могилой отсутствовали и зафиксированы в развале за пределами могилы и ограды (рис. 6, 4). В заполнении могильной ямы (плотная супесь) фиксировались фрагменты каменных конструкций могилы, костей скелета погребенного, керамики, бронзовых изделий и пастовых бус (рис. 6, 6-8). Погребальная камера также устроена по принципу «бесика». На дне в результате ограбления могилы вещевого материала и фрагментов костей погребенного не обнаружено (рис. 6, 5).

Погребение 6 пристроено с западной стороны от конструкции, вероятно, значительно позднее, так как никаких конструктивных элементов в виде ограды вокруг нее не наблюдается. Кроме того, оно залегало на $30 \mathrm{~cm}$ ниже уровня плит цепочки каменных оград по уровню древней поверхности за пределами возвышенности, где были устроены предыдущие захоронения. Вследствие этого погребение оказалось совершенно непотревоженным (рис. 7, 1). Оно представляло собой каменный ящик $(1,5 \times 0,7$ м), перекрытый сверху тремя массивными каменными плитами поперек могилы. Поверх них фиксируется наброска из камней мелких и средних размеров вперемешку с грунтом, что предполагает сооружение над ним невысокого могильного холма (30-40 см).

Заполнение могильной ямы влажная рыхлая супесь, из-за чего костные останки погребенного плохо сохранились. Форма погребальной камеры также напоминает «бесик», так как западная и восточная стенки выше северной и южной на 20-30 см и ниже дна могилы на 10 см. На дне (65 см) обнаружены кости скелета, уложенного в скорченном виде на левом боку, головой на запад (рис. 7, 2, 3). У западной стенки перед лицом умершего установлен керамический сосуд, орнаментированный каннелюрами по шейке (рис. 7, 4).

Исследованные захоронения эпохи бронзы имеют достаточно устойчивые признаки как в устройстве надмогильных сооружений (цепочка каменных оград прямоугольной формы), так и погребальных конструкций (каменные ящики типа «бесик»). Их сходство заключается также в способе сооружений данных конструкций из каменных плит, вкопанных на ребpo. Некоторой особенностью этих объектов является вкапывание вдоль стенок могил с внешней стороны дополнительных невысоких плит, достигающих длины от 30 до 150 см. Все могилы перекрывались 2-3 крупными плоскими плитами и наброской из камней мелких и средних размеров. Над погребением 6 фиксируются следы невысокой каменно-земляной насыпи.

Общей особенностью некоторых каменных ящиков крупных погребальных комплексов региона является тот факт, что на могильниках Кожабала-I, Тесик-I, Мадьярсай-I и Ой-Джайляу-III западные и восточные стенки могил явно возвышались над другими и были закопаны глубже северных и южных на 20-40 см [Горячев, 2020, с. 144]. Это дает возможность предполагать, что погребения умышленно повторяли конструкцию 
Горячев А.А., Потапов С.А., Чернов М.А. Погребальный комплекс эпохи бронзы ...
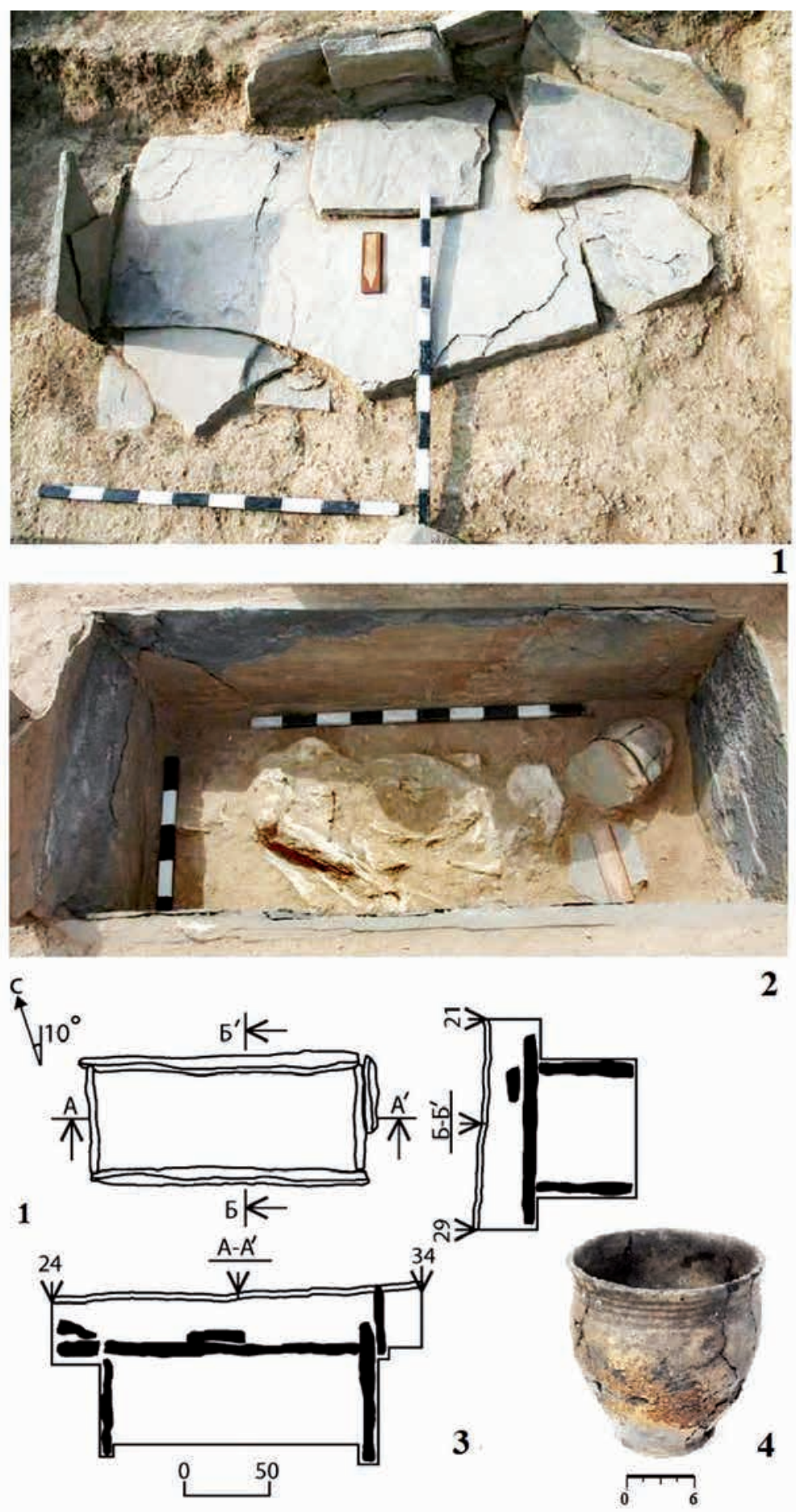

Рис. 7. Тесик-I, конструкция 1, n. 6: 1 - фото могилы до расчистки; 2 - фото захоронения в $n$. 6; 3 - план и разрезы погребальной камеры; 4 - керамический сосуд

Fig. 7. Tesik-I, construction 1, burial 6: 1 -photo of the grave before clearing; 2 - photo of the burial in item 6; 3 -plan and sections of the burial chamber; 4 - ceramic pot 
детской колыбели - «бесика». Эта традиция получила распространение среди могильников эпохи бронзы Шу-Илейских гор и связана, вероятно, с религиозными представлениями о перерождении души после смерти.

Подобное устройство надмогильных конструкций (за исключением погребения 6) в других районах Жетысу отмечено в горной зоне Иле и Жетысу Алатау в смешанных алакульско-федоровских погребальных комплексах [Марьяшев, Горячев, 1993; Гасс, Горячев, 2016, с. 88]. Близкие аналогии этим погребальным конструкциям прослеживаются в материалах центрально-казахстанских могильников Айшрак, Былкылдык I и Шет I [Маргулан и др., 1966, с. 91, 95, 105, 107; Кадырбаев, Курманкулов, 1992, с. 86-89], которые относятся к алакульско-атасускому этапу развития культур эпохи бронзы Казахстана. Однако традиция сооружения земляных насыпей над каменными ящиками либо конструкциями в виде оград ближе федоровско-нуринской группе в семиреченских и центральноказахстанских материалах андроновских племен [Максимова, 1961; Маргулан и др., 1966, с. 90, 98, 117; Кадырбаев, Курманкулов, 1992, с. 78, 82; Рогожинский, 1999 , с. $11,13,15$, 29, 30].

Заполнение могильных ям позволяет предполагать, что останки умерших засыпали принесенным песчанистым грунтом сразу после помещения в погребальную камеру. Умерших внутри данной конструкции хоронили по обряду трупоположения в скорченном виде на левом боку головой на запад. В изголовье погребенных устанавливалась керамическая посуда (от одного до трех сосудов). Бронзовые и глиняные изделия, об- наруженные среди костных останков внутри могил, являлись деталями и украшениями погребальной одежды.

Описание вещевого материала могильника Тесик-I

Вещевой материал представлен набором бронзовых украшений, в том числе и плакированных золотой фольгой, пастовых бус и керамической посудой. Среди изделий из бронзы отмечены фрагменты браслетов со спиралевидными окончаниями, накосников листовидной формы, нашивные бляшки овальной формы, желобчатые серьги-подвески в 1,75 оборота, декоративная ременная обойма и нитки бус. Результаты эмиссионного спектрального анализа металлических изделий в регионе показывают, что большинство из них относится к категории оловянистых бронз с разным процентным содержанием меди, олова и примесей. Подобные различия отражают состояние местной горнорудной базы и разнообразие технических приемов и технологий производства бронзы в регионе. Это дает нам основание предполагать, что некоторые из них, вероятно, могут свидетельствовать о заимствовании традиций производства металла у мастеров кузнечного ремесла Центрального Казахстана, где технологии производства оловянных бронз были более развиты [Берденов, 1998; Маргулан и др., 1966, с. 269; Кадырбаев, Курманкулов, 1992]. Анализ их позволяет уточнить датировку могильника в рамках относительной хронологии.

Браслеты со спиралевидными окончаниями (рис. 3, 9) являлись в регионе атрибутом женских захоронений [Усманова, 2010, с. 149-152; Горячев, 2020, с. 149-151]. Они сформированы на вогнутой пластине, 
Горячев А.А., Потапов С.А., Чернов М.А. Погребальный комплекс эпохи бронзы ...

сомкнутой почти в полное кольцо, диаметром $\sim 6-7$ см. Концы заготовок прокованы на уплощение с утончением и свернуты в спирали конической формы по часовой стрелке в 4-5 завитков. Концы украшений отличаются спиралями высокой конической формы (1,2-1,5 см) с обеих сторон и относятся специалистами к федоровской культурной традиции АКИО* (*здесь и далее АКИО - андроновская культурно-историческая общность) [Аванесова, 1991, с. 69]. Подобные браслеты известны в материалах других регионов Жетысу среди захоронений кульсайского типа, относящихся к местному варианту федоровсконуринской культуры [Гасс, Горячев, 2016 , рис. $6,37-39 ; 10,18,19]$ и андроновских погребальных комплексов Центрального Казахстана [Маргулан и др., 1966, с. 84, 86], Урала и Притоболья [Зданович, 1988, с. 170 , табл. 10В; Потемкина, 1985, рис. 88, $10,11]$.

Накосники из могильника Тесик-I по типологии украшений относятся к плоским нашивным бляшкам (рис. 3, 8; 6, 8). Из двух листовидных пластинчатых элементов накосников фрагментарно сохранился только один длиной 50 мм ( 70-80 в полном виде) и шириной 20 мм в широкой части. Выполнены методом проковки тонкого медного листа (1 мм).

На территории Жетысу такие изделия известны в материалах могильника Куйган-II долины реки Коксу у западных отрогов Жетысу Алатау [Горячев, Чернов, 2017, рис. 4, 18, 19]. Эти накосные нашивные бляшки декорированы методом чеканки «древовидным» орнаментом, что отличает их от других аналогов на территории Казахстана. Подобные по форме накосники изучены среди материалов центрально- и североказахстанских могильников Бестамак, Лисаковский, Бозенген, Токанай-I, Шондыкорасы-I [Усманова, Логвин, 1998, с. 30-33], где они вписываются в период от синташтинско-петровского до алакульского периода эпохи бронзы данных регионов.

Среди нашивных плоских бляшек могильника Тесик-I выделяется группа крупных слегка выпуклых изделий овальной формы (рис. 8, 1-4). Они изготавливались из бронзового листа методом ковки и имеют размеры - 45,8×35,3 мм, 40,8×33,4 мм, $31,2 \times 32,3$ мм и $34,6 \times 24,6$ мм. В верхней части бляшек пробиты отверстия (1-2,5 мм) для нити или шнурка. При общем большом сходстве эти украшения не одинаковы ни в размерах, ни по форме. Это позволяет утверждать, что при их производстве не использовался шаблон. Бляшки декорированы по центру и периметру пуансонным орнаментом в виде линий из «точек», выступающих над поверхностью изделия на 1-2 мм. От центральной линии под разными углами отходят еще несколько рядов точек, которые образуют разнообразные геометрические узоры «древовидной» и зигзагообразной форм.

Подобная орнаментация в регионе характерна для листовидных элементов накосников долины реки Коксу (могильник Куйган-II) и встречается в материалах смешанных алакульско-федоровских комплексов Центрального и Восточного Казахстана [Аванесова, 1991, рис. 49]. Сами изделия близки серии округлых плоских и выпуклых бляшек из разных могильников региона, которые минимум в 1,5-2 раза меньше этих [Горячев, Чернов, 2020, рис. 6, 1-20]. В памятниках андроновского ареала похо- 
жие бляшки (все соразмерные имеют обязательно округлую форму и другие виды орнаментации) нам не известны и, вероятно, могут являться местной вариацией распространенного вида украшений одежды.

Другую серию металлических изделий представляют бронзовые желобчатые серьги-подвески в
1,75 оборота, плакированные золотой фольгой. Листочкам придан выпукловогнутый вид (рис. 3, 7). Медная заготовка основы в виде стержня была длиной 80 мм. По образцу ей методом проковки придавалась форма в виде двух листков (7 мм), соединенных перешейком (3-4 мм). Толщина заготовки в области перешейка 1 мм, а ли-
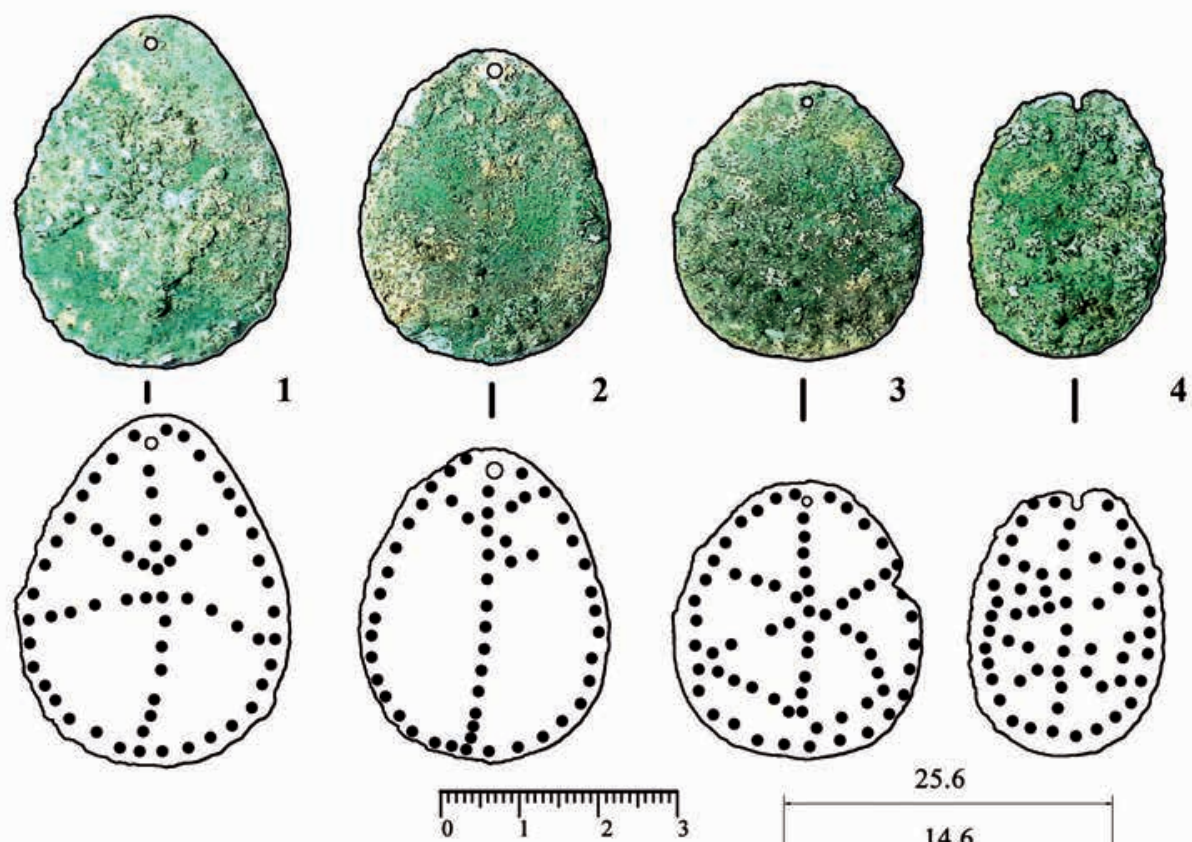

25.6
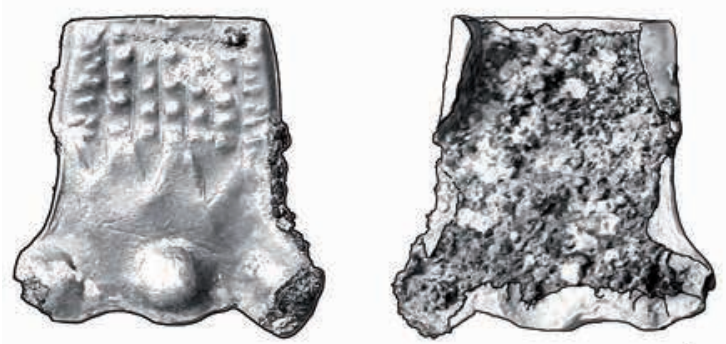

6

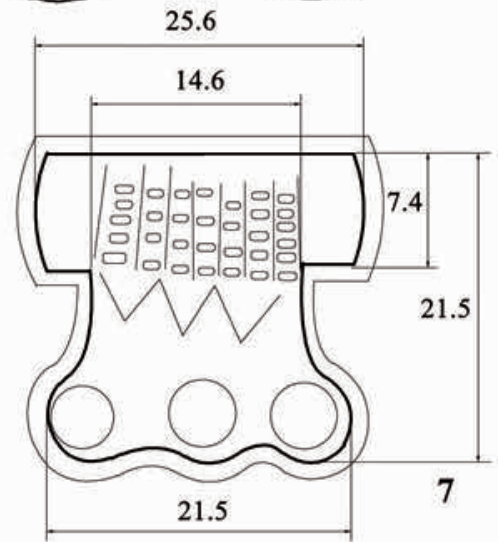

Рис. 8. Тесик-I. Виды декора металлических изделий из ограды 1 n. 1:

1-4 - нашивные бляшки овальной формыл; 5-7 - декоративная ременная обойма

Fig. 8. Tesik-I. Types of decoration of metal products from the fence 1 burial 1: 1-4-oval-shaped patch plaques; 5-7-decorative belt clip 
Горячев А.А., Потапов С.А., Чернов М.А. Погребальный комплекс эпохи бронзы ...

сточки $-0,7$ мм. Под основу из меди подкладывалась заготовка из золотой фольги (толщиной 0,1 мм) несколько превышающая ее размеры. Лопастям медной заготовки, плакированным золотой фольгой, придаётся выпуклая форма посредством тиснения. Все изделие сворачивается в кольцо соответствующего количества оборотов.

Такие изделия имели определенное своеобразие в каждом регионе своегораспространения. В Шу-Илейских горах значительная их часть плакирована золотой фольгой [Горячев, 2020, с. 150-151]. Подобные серьгиподвески являются частью головных украшений бронзового века по всей степной Евразии как в алакульских, так и федоровских погребениях андроновского ареала [Аванесова, 1991, с. 53 , 54, рис. 43; Куприянова, 2008 , с. 24-26, рис. 13; Усманова, 2010, с. 64 , рис. 13$]$.

Бронзовая ременная обойма, плакированная золотой фольгой, представляет интерес как технологией изготовления, так и своим декоративным оформлением (рис. 8, 5-7). Конструктивная основа обоймы была выполнена из листа меди Т-образной формы. Толщина бронзовой пластины 0,6-0,7 мм, золотой фольги - 0,1 мм. Длина изделия 21,5 мм, ширина основная 14,6 мм, в нижней части 21,5 мм. Ширина пластины по клапанам в развертке 25,6 мм, ширина клапанов 7,4 мм. Рельефный рисунок в центральной части обоймы создавался методом чеканки и тиснения. На заполненную рельефом пластину накладывался соответствующей формы лист золотой фольги и через мягкий, но плотный материал с усилием прижимался к основе. Рисунок рельефа отпечатывался на фольгу. Заготовка переворачивалась вниз лицом и края золотой фольги загибались на оборотную сторону. В завершение по контуру элементов орнамента наносились точечные удары тонким металлическим пуансоном для усиления рельефа.

На вертикальный элемент был предварительно нанесен узор в виде узких и коротких горизонтальных полос, зигзага и полусферических выпуклостей. Форма орнамента и порядок следования элементов заранее определены. Вертикальная полоса заготовки разделена на три яруса. Верхний заполнен восемью вертикальными полосками, которые образуют семь колонок, внутри которых нанесены от четырех до шести узких и коротких горизонтальных полос. Ниже проходит неровная зигзагообразная линия с пятью изломами, имеющих разные углы склонения. Третий ярус орнаментальной композиции представляет ряд из трех выпуклых полусфер.

Уже после плакирования концы медной обоймы обжимались вокруг вертикально расположенного ремня. Подобный тип ременных обойм с геометрическим орнаментом не известен в материалах андроновских комплексов, но характерен для региона Шу-Илейских гор. В частности, две подобные обоймы схожей технологии и орнаментации обнаружены в погребальном комплексе раннеандроновского периода Мадьярсай-I [Горячев, 2020а, с. 146, рис. 6, 1]. Характер их орнаментации близок символике нашивных бляшек головного убора женского костюма андроновских женщин [Усманова, 2010, с. 91-93] и бронзовых обойм Южного Зауралья и Казахстана [Куприянова, 2008, с. 29, рис. 18, 1-3]. Близкие аналогии этим узорам прослеживаются в лапчатых подвесках федоровской культурной традиции [Усманова, 2010, рис. 48]. 
На наш взгляд, они являются результатом развития художественных традиций ювелирного искусства эпохи бронзы Шу-Илейского региона.

Наиболее массовым металлическим инвентарем погребений эпохи бронзы в регионе являются бусы биконической и прямоугольной форм (рис. 3, 11, 12; 5, 7-9; 6, 6). Они изготавливались из медной проволоки и являлись важным элементом декора одежды племен эпохи бронзы Центральной и Средней Азии [Аванесова, 1991, рис. 61]. В материалах захоронений встречаются также пастовые бусы белого цвета продолговатой формы ребристого типа (рис. 3,$13 ; 5,10,11$; $6,7)$. Они отличаются друг от друга цветовой гаммой голубоватого и зеленоватого оттенков. Ими обшивались по периметру обшлага рукавов, края платьев и наружная поверхность обуви. Чаще всего оба вида инвентаря представляли собой нитки до нескольких десятков однотипных бусин, что характерно как для федоровских захоронений на территории Жетысу [Гасс, Горячев, 2016, рис. 5, 10], так и для алакульских могильников Центрального Казахстана и Южного Зауралья [Усманова, 2010, с. 147-148].

Керамический материал могильника Тесик-I представлен коллекцией из шести археологически целых и четырех фрагментированных лепных широкогорлых плоскодонных керамических сосудов. Среди них отмечены семь горшков и две банки, и еще три фрагмента одного сосуда, не позволяющих определить его точную форму. Общие формы посуды демонстрируют приземистые сосуды (высотой 93-196 мм) с высокой или короткой шейкой с открытым устьем (диаметром 111-180 мм) с четко или слабо выраженным уступчиком (диа- метр 120-170 мм), либо плавно профилированным плечиком (диаметром 122-185 мм). Тулова горшков с профилированным плечиком шире устья сосудов, а с ребристым плечиком или уступчиком наоборот уже. Диаметры дна сосудов варьируются от 60 до 111 мм.

В процессе изготовления сосудов допускалась их ритуальная порча посредством низкокачественного производства или преднамеренного разрушения. Так сосуд 3 из погребения 1 (рис. 3,5$)$, несмотря на хорошее качество изготовления, имел несколько утрат своей изначальной формы. На внешней стороне стенки, от середины тулова к донцу, произошло отслоение поверхности локальным пятном, площадью около 15 см² $^{2}$ без нарушения целостности стенки сосуда. Вторая крупная утрата в форме сосуда, это отсутствие половины венчика с прилегающими частями (шейка, плечико, тулово) сосуда. Отсутствующая часть как бы срезана под углом $30^{\circ}$ от середины венчика к наружи, до 65 мм высоты от донышка по стенке. Срез был произведён намеренно, вероятно, еще до обжига, но по подсохшему черепку. Об этом говорит достаточно ровная линия среза с легко открошившимися краями и два участка по линии среза на стенке примерно $1 \div 1,5$ см длины, сохранившими плоскость среза. Таким образом, можно говорить об одномоментном отсечении фрагмента верхней части сосуда, в одно движение. Возможно, такое действие было связано с ритуальным разрушением погребальных сосудов. В этом случае можно предположить факт соблюдения ритуала, но с сохранением функциональных свойств сосуда. Возможно, сосуд предназначался под жидкости. 
Горячев А.А., Потапов С.А., Чернов М.А. Погребальный комплекс эпохи бронзы ...

В сосуде 1 из погребения 1 (рис. 9, 5) горшок имеет по венчику ряд растрескиваний, направленных к донцу. Несколько трещин неглубокие и достигают шейки или плечика сосуда. Две средних по длине, одна из которых доходит до середины высоты горшка, другая несколько ниже. Последняя, самая глубокая, достигла донышка сосуда. По сторонам от средних трещин, на уровне шейки сосуда имеется две пары отверстий диаметром 4 мм. Отверстия имеют ровные края и проделаны были с целью укрепить стенки горшка метал- лическими скобами или стяжкой из сыромятного ремешка. Но одно из четырех отверстий просверлено было не до конца, не насквозь. Возможно, в ходе сверления возникла новая и большая трещина, и чтобы сосуд не разрушился окончательно, починка была приостановлена, и в ритуале погребения горшок использовался в состоянии близком к разрушению. Если по окончании погребального ритуала горшки разрушались намеренно, то, возможно, этот горшок был воспринят как уже разрушенный и искусственно ломать его не стали. Находящийся в
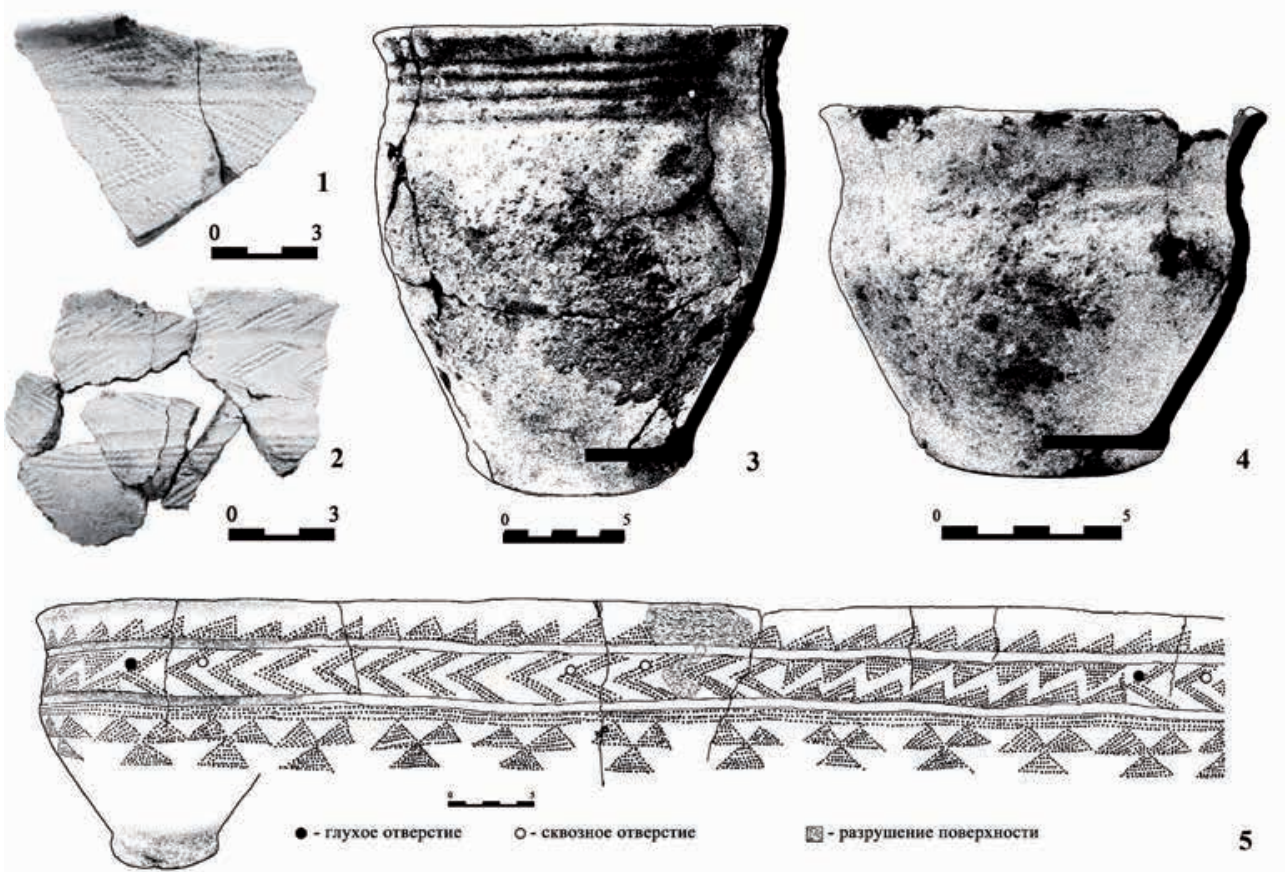

Рис. 9. Тесик-I. Орнаментальные мотивы на керамической посуде: 1, 2 - фрагменты керамики из п. 2; 3- сосуд из n. 6; 4- сосуд из n. 5; 5 - развертка орнаментального декора на сосуде 1 из $n .1$

Fig. 9. Tesik-I. Ornamental motifs on ceramic dishes: 1, 2-fragments of ceramics from burial 2; 3 - a vessel from burial 6; 4 - a vessel from burial 5;

5 - a sweep of ornamental decoration on vessel 1 from burial 1 
стабильных условиях погребения, без воздействия извне, горшок, будучи треснутым, смог дойти до нас практически целым.

Низкое качество произведенной посуды демонстрирует сосуд из погребения 6 (рис. 9, 3). Керамическая масса отощена большим содержанием песка, что не могло позволить получить изделие высокого качества. По поверхности горшка имеются множественные пятна отслоения верхнего слоя. Общая характеристика: керамическое рыхлое тесто промято неосновательно, что после низкотемпературного обжига (500-600 $\mathrm{C}^{\circ}$ ) с низким содержанием кислорода в восстановительной (дымной) среде не могло дать керамики хорошего качества.

Такая посуда не применялась в быту. Тем не менее на её стенке по бокам от двух трещин имеются сверленые отверстия на уровне шейки диаметром 3 мм. Они предназначались для ремонта горшка, посредством стяжки стенки по трещине, металлическими скобами. Сами скобы не сохранились, но в отверстиях остались их фрагменты в виде медных стержней, покрытых оксидом зелёного цвета. Следы починки в данном случае выступают как свидетельство низкого технологического качества посуды, на которой уже вскоре после обжига образовался ряд трещин. Чтобы сосуд мог использоваться в погребальном ритуале, его пришлось тут же реставрировать.

Остальная часть сосудов имеет повреждения в виде множественных трещин технологического характера. Косвенные результаты палинологического анализа показывают, что вся посуда изготавливалась непосредственно перед погребением. Следы использования ее в быту отсутствуют.
Напрашивается вывод, что подобные нарушения были вызваны требованиями ритуальной практики.

Естественнонаучные исследования почв из керамической посуды в захоронениях бронзового века региона, проведенные в лаборатории Института геологических наук им. К. И. Сатпаева (д.г.-м.н. С. А. Нигматова), показали отсутствие в ней растительной пищи. Их палинологическое изучение позволило предположить, что в посуде могли находиться вода, молоко или бульон. На могильнике Тесик-I сосуды заполнялись грунтом уже в процессе захоронения.

Декор отмечен на трех целых и двух фрагментированных сосудах (рис. 9), что составляет около $40 \%$ от их общего числа и значительно превышает долю орнаментированной керамики в погребальных комплексах региона (не более 10\%). Геометрический орнамент нанесен гребенчатым штампом. Каннелюры образованы проведением, с лёгким вдавливанием, инструмента в виде цилиндрического стержня. Наиболее интересная орнаментальная комбинация отмечена на сосуде 1 погребения 1 (рис. 9, 5). Она представлена тремя фризами, расположенными один над другим. Каждая орнаментальная полоса отделена от следующей каннелюром. Пропорции в орнаментальной зоне: ширина каннелюр 5 мм, общая длина пояса 49,5 см по средней линии; зигзагообразный орнамент имеет длину $17 \mathrm{~cm}$, полоса из шевронов имеет длину 32,5 см.

Верхний регистр выполнен традиционно, в виде ряда косых треугольников, обращенных вершинами вверх. Во втором регистре орнамент составлен из двух полос, следующих друг за другом: зигзагообразный орнамент и полоса из шевроновидных 
Горячев А.А., Потапов С.А., Чернов М.А. Погребальный комплекс эпохи бронзы ...

элементов, лежащих на боку. Зигзаг образован двумя рядами треугольников, вершины которых смотрят на соединение углов оснований треугольников противоположного ряда. Промежуток отстояния рядов образует зигзаг, как элемент орнамента. Шевронообразные элементы также отстоят друг от друга на собственную ширину. Так фон между элементами образует аналогичный декор. Третий регистр орнамента также состоит из двух элементов. По верхнему краю идет полоса из трех линий, оставленных штампом. К ней примыкают снизу декоративные элементы, составленные из трех равнобедренных треугольников, два вверху - один внизу, обращенных вершинами вверх. Два верхних касаются вершинами полосы и углами оснований друг друга. К этим углам снизу своей вершиной примыкает третий треугольник. Группы отстоят друг от друга примерно на $1 / 2$ треугольника.

Та же орнаментальная композиция прослеживается по верхнему и среднему регистрам на двух фрагментах керамического сосуда из погребения 2 (рис. 9, 1, 2). Из декоративных элементов на горшке из погребения 5 отмечен единственный выступ-рубчик, который опоясывает шейку сосуда (рис. 9, 4). Шейка горшковидного сосуда изящной формы из погребения 6 декорирована полосой, состоящей из четырех продольных желобков - выкружек, сомкнутых в кольцо.

Подобной формы сосуды были широко распространены и в ШуИлейском регионе, и в предгорной и горной зоне Иле и Жетысу Алатау [Марьяшев, Горячев, 1993; Гасс, Горячев, 2016]. Керамика с подобными признаками достаточно широко рас- пространена в материалах алакульскоатасуских и федоровско-нуринских комплексах Центрального и Восточного Казахстана [Маргулан и др., с. 111, 115; Кадырбаев, Курманкулов, 1992, рис. $37,66,84$; Черников, 1960, с. 88]. В своей работе по типологии форм сосудов Е. Е. Кузьмина соотносит их с алакульскими и федоровскими традициями центрально-казахстанского керамического производства андроновского этапа эпохи бронзы [Кузьмина, 1986].

Орнаментальные мотивы керамической посуды из двух центральных захоронений 1 и 2 могильника Тесик-I типичны для погребальных комплексов Шу-Илейского региона, где они встречаются в материалах наиболее ранних захоронений могильников Кожабала-I, Ой-ДжайляуIII, Тамгалы-I, II и VI [Горячев, 2020, c. 149 , рис. 7, 1-9]. Подобная орнаментальная традиция характерна для алакульских комплексов как других районов Жетысу [Марьяшев, Горячев, 1993], так и Центрального Казахстана [Маргулан и др., 1966, с. 115]. Орнаментация посуды рядами каннелюр на территории Жетысу более характерна здесь для керамического инвентаря позднеандроновских захоронений.

\section{Обсуждение результатов}

Анализ планиграфии погребального комплекса могильника Тесик-I позволяет предположить, что первоначальным сооружением конструкции 1 была крупная центральная ограда, разделенная на три секции (ограды 1-3). Однако могильные конструкции зафиксированы только в ее центральной и северной частях. Схожесть их устройства позволяет предполагать, что захоронение в них производились одномоментно либо в очень близкие 
по времени сроки. Это подтверждается и однотипным погребальным инвентарем. В каждое захоронение было в изголовье установлено по три керамических сосуда. Характер вещевого материала, дает основание считать, что в могиле 1 устроено захоронение женщины (браслеты, накосник, декоративная ременная обойма, овальные нашивные бляшки). В могиле 2 был погребен, предположительно, мужчина (фрагментарность костных останков пока не позволяет установить этот факт антропологически).

Анализ конструктивных особенностей и вещевого инвентаря дает основание считать, что в них погребены представители смешанной алакульско-федоровской группы населения андроновского периода эпохи бронзы. В материалах захоронений культурная доминанта скорее принадлежит алакульско-атасуской традиции племен АКИО Центрального Казахстана. Все последующие погребальнопоминальные конструкции пристраивались к основной ограде с южной и западной сторон позднее.

Интересен тот факт, что в могилах 1 и 2 присутствует горшковидная керамическая посуда как уступчиком по плечику, так и с плавной профилировкой тулова. В более поздних материалах керамическая посуда имеет исключительно плавный профиль плечика, особенно в погребении 6, которое конструктивно отличается от других захоронений данного комплекса. Эта могила не пристраивалась к более ранней ограде, а скорее была организована рядом с ней под отдельной грунтовой насыпью. Обычай заполнения погребальной камеры просеянным речным песком, зафик- сированный здесь, на территории Жетысу встречается преимущественно среди населения с ярко выраженными федоровско-нуринскими культурными традициями [Гасс, Горячев, 2016, c. 88].

По своим конструктивным признакам и особенностям погребальных традиций данный комплекс относится к семейным оградам, характерным для позднеалакульского периода раннеандроновского периода в ШуИлейском регионе. Подобные семейные ограды исследованы на могильниках Кожабала-I, Ой-Джайляу-VII, Тамгалы-I и II. Основная часть подобных конструкций по материалам и радиоуглеродным датировкам относится к XVII-XVI вв. до н.э. [Горячев, 2020 , с. 139, табл. 1]. В тоже время отдельное захоронение в погребении 6 ближе соответствует традициям позднеандроновского периода эпохи бронзы региона, который датируется XVXIV вв. до н.э. [Горячев, 2020, с. 154]. С учетом того, что на могильнике отмечены разнотипные погребальные конструкции бронзового века, следует отметить, что исследованный погребальный комплекс отражает только один небольшой хронологический период функционирования могильника, вероятней всего, в пределах XVIXV вв. до н.э.

Могильник Тесик-I сложноструктурный памятник, который состоит из разнотипных и разновременных погребальных комплексов, что позволяет предположить его значение как центрального погребального комплекса бронзового века северных склонов гор Айтау. Ближайшие аналогичные памятники расположены в соседних горных ущельях гор 
Горячев А.А., Потапов С.А., Чернов М.А. Погребальный комплекс эпохи бронзы ...

Жынгылды в 30 км к юго-востоку и в урочище Кожабола гор Хантау в 40 км к северо-западу. Также, как и в комплексе Тесик они представляют собой крупные могильники, насчитывающие несколько десятков захоронений (Кожабала-I - более 150).

Вещевой и керамический материал погребального комплекса Тесик в горах Айтау достаточно разнообразен по формам и технологиям изготовления, однако вполне традиционен для различных комплексов эпохи бронзы Жетысу. Сочетание признаков алакульско-атасуской и федоровсконуринской традиций АКИО является хорошим хронологическим репером, a с учетом структурной организации могильника может помочь в реконструкции процесса заселения племенами бронзового века территории Шу-Илейского региона Жетысу.

\section{Bblводbl}

Таким образом, основываясь на ранее проведенных исследованиях погребальных комплексов, мы можем отметить, что могильник Тесик-I имеет целый ряд признаков, объединяющих его в общую культурную традицию бронзового века Шу-Илейского региона. Она имеет свои отличия в структуре комплексов в целом, в организации погребальных сооружений и обряде захоронения, которые отличают ее от культурных традиций населения эпохи бронзы других регионов Жетысу, но сближают с центральноказахстанскими в силу одинаковых природно-климатических условий, а также некоторых аспектов хозяйственного и историко-культурного развития. Характер погребальных традиций, отмеченных в материалах могильника Тесик-I, свидетельствует о значительной степени этнокультурных взаимосвязей между населением этих сопредельных регионов.

Сам могильник был устроен на ровной площадке близ сопки с петроглифами, что является характерной чертой для структурной организации комплексов эпохи бронзы в восточной и центральной части основной горной гряды ШуИлейского междуречья от гор Айтау и Кулжабасы до хребтов Анрахай и Серектас. Археологический комплекс эпохи бронзы в урочище Тесик представлял собой достаточно типичный вариант для региона, когда вокруг крупного древнего кладбища, на котором хоронили представителей различных родовых групп, формируется сакральных комплекс с петроглифами, а жители урочища помимо хозяйственных функций выполняли еще и общественную функцию «хранителей традиций».

Интенсивныеконтактыдревнего населения Сарыарки и Шу-Илейского междуречья способствовали формированию в местных погребальных комплексах смешанных алакульскофедоровских черт. В материалах могильников и реконструкциях погребальных традиций прослеживаются признаки двух культурных доминант - пришлой алакульско-атасуской и местной федоровско-нуринской, составлявших основу АКИО на территории Казахстана. Материалы исследований могильника показали, что период его функционирования относится как к раннему (XIX-XVI вв. до н.э.), так и к позднему андроновским этапам бронзового века (XV-XIV вв. до н.э.). Прежде всего, различия ка- 
саются надмогильных сооружений (крупные коллективные цепочки и семейно-родовые конструкции оград). На позднем этапе они трансформируются в создание коллективных и индивидуальных курганов и оград. Погребальные традиции бронзового века населения двух соседних регионов свидетельствуют о значительной степени социально-экономических и этнокультурных взаимосвязей между ними, что делает дальнейшие исследования перспективными.

\section{ЛИТЕРАТУРА}

1. Аванесова Н.А. Культура пастушеских племен эпохи бронзы азиатской части СССР (по металлическим изделиям). Ташкент: Изд-во «ФАН», 1991. 200 с.

2. Берденов С.A. Казахстанская горно-металлургическая область // Вопросы археологии Казахстана / отв. ред. 3. Самашев. Алматы-М.: «Ғылым», 1998. Вып. 2. C. $180-190$.

3. Воякин Д.А., Горячев А.А., Потапов С.А., Ильин Р.В. Методика археологических исследований и маркировка маршрутов древних миграций на территории Хантауского транзитного коридора // ИАС. 2020. Вып. 7. С. 91-116.

4. Гасс А., Горячев А.А. К вопросу о типологии и хронологии могильников эпохи бронзы в высокогорной зоне Заилийского Алатау // Вестник НГУ. Сер. История, филология. 2016. Т. 15, № 5. С. 85-123.

5. Горячев А.А. Погребальные комплексы бронзового века Хантауского транзитного коридора // ИАС. 2020. Вып. 7. С. 135-157.

6. Горячев А.А. Могильник бронзового века Мадьярсай-І // ТиПАИ. 2020а. № 1 (29). C. 135-151. https://doi.org/10.14258/tpai(2020)1(29).-09

7. Горячев A.A., Чернов М.A. Металлический инвентарь из погребальных комплексов эпохи бронзы Жетысу // Известия НАН РК. Серия обществ. и гум. наук. 2017. № 1 (311). C. 5-24.

8. Горячев А.А., Чернов М.A. Металлические изделия из погребальных комплексов эпохи бронзы Хантауского транзитного коридора // Вестник КарГУ им. Е.А. Букетова. Сер. История. Философия. 2020. № 3 (99). С. 54-70.

9. Зданович Г.Б. Бронзовый век Урало-Казахстанских степей. Свердловск: Издво Урал. ун-та, 1988. 184 с.

10. Кадырбаев М.К., Курманкулов Ж. Культура древних скотоводов и металлургов Сары-Арки. Алма-Ата: Гылым, 1992. 250 с.

11. Кузьмина E.E. Гончарное производство у племен андроновской культурной общности // Восточный Туркестан и Средняя Азия в системе культур древнего и средневекового Востока. М.: Наука, 1986. С. 152-182.

12. Куприянова E.B. Тень женщины: Женский костюм эпохи бронзы как «текст»: (по материалам некрополей Южного Зауралья и Казахстана). Челябинск: АвтоГраф, 2008. $244 \mathrm{c}$.

13. Максимова А.Г. Могильник эпохи бронзы в урочище Каракудук // Новые материалы по археологии и этнографии Казахстана. Алма-Ата: Изд-во АН КазССР, 1961. T. 12. C. $62-71$.

14. Маргулан А.Х., Акишев А.К., Кадырбаев М.К., Оразбаев А.М. Древняя культура Центрального Казахстана. Алма-Ата: Наука, 1966. 436 с.

15. Марьяшев А.Н., Горячев А.А. Вопросы периодизации и хронологии памятников эпохи бронзы Семиречья // РА. 1993. № 1. С. 5-19. 
Горячев А.А., Потапов С.А., Чернов М.А. Погребальный комплекс эпохи бронзы ...

16. Потемкина T.M. Бронзовый век лесостепного Притоболья. М: Наука, 1985. $376 \mathrm{c}$.

17. Рогожинский A.Е. Могильники эпохи бронзы урочища Тамгалы // ИАС. 1999. C. 7-43.

18. Усманова Э.Р. Костюм женщины эпохи бронзы Казахстана. Караганда: ТАиС, 2010. $176 \mathrm{c.}$

19. Усманова Э.Р., Логвин В.Н. Женские накосные украшения Казахстана: (эпоха бронзы). Караганда-Лисаковск: КарГУ им. Е.А. Букетова, Кустанайский госуниверситет, 1998. 64 с.

20. Черников С.C. Восточный Казахстан в эпоху бронзы / Материалы и исследования по археологии СССР, № 88. М.-Л.: АН СССР, 1960. 285 с.

\section{REFERENCES}

1. Avanesova, N. A. 1991. Kultura pastusheskih plemen epohi bronzy aziatskoy chasti SSSR (po metallicheskim izdeliyam) (Culture of pastoral tribes of the Bronze Age of the Asian part of the USSR (by metal products)). Tashkent: "FAN" Publ. (in Russian).

2. Berdenov, S. A. 1998. In: Samashev, Z. (ed.) Voprosy arheologii Kazahstana (Issues of archeology of Kazakhstan), 2, 180-190. Almaty; Moscow: "Gylym” Publ. (in Russian).

3. Voyakin, D. A., Goryachev, A. A., Potapov S.A., Iliin, R. V. 2020. In: Istoriya $i$ arheologiya Semirechiya (History and archaeology of Semrechie), 7, 91-116 (in Russian).

4. Gass, A., Goryachev, A. A., 2016. In: Vestnik NGU. Seriya istoriya, filologiya. (Bulletin of Novosibirsk State University. Series history, Philology). T. 15, № 5. 85-123 (in Russian).

5. Goryachev, A. A. 2020. In: Istoriya i arheologiya Semirechiya (History and archaeology of Semrechie), 7, 135-157 (in Russian).

6. Goryachev, A. A. 2020a. In: Teoriya i praktika arheologicheskih issledovaniy (Theory and practice of archaeological research), 1 (29), 135-151. https://doi.org/10.14258/ tpai(2020)1(29).-09. (in Russian).

7. Goryachev, A.A., Chernov, M.A. 2017. In Izvestiya NANRK. Seriya obshchestvennyh $i$ gumanitarnyh nauk (News of the NAS of the Republic of Kazakhstan. Ser. Social Sciences and Humanities), 1 (311), 5-24 (in Russian).

8. Goryachev, A. A., Chernov, M. A. 2020. In Vestnik KGU im. E.A. Buketova. Seriya Istoriya. Filosofiya. (Bulletin of E.A. Buketov Karagandy State University. History series. Philosophy), 3 (99), 54-70 (in Russian).

9. Zdanovich, G. B. 1988. Bronzovyi vek Uralo-Kazahstanskih stepey (Bronze Age of the Ural-Kazakhstan steppes.). Sverdlovsk: "Ural university” Publ. (in Russian).

10. Kadyrbayev, M. K., Kurmankulov, Zh. 1992. Kultura drevnih skotovodov $i$ metallurgov Sary-Arki (Culture of cattlemen and metallurgists from Sary-Arka). Alma-Ata: "Gylym" Publ. (in Russian).

11. Kuzmina, E. E. 1986. In: Vostochnyi Turkestan i Srednyaya Asia v sisteme kultur drevnego i srednevekovogo Vostoka (East Turkestan and Central Asia in the system of cultures of the ancient and medieval East). Moscow: "Nauka" Publ., 152-182 (in Russian).

12. Kupriyanova, E. V. 2008. Ten zhenshchiny: Zhenskiy kostyum epohi bronzy kak "tekst" (po materialam nekropoley Yuzhnogo Zauralija i Kazahstana) (The Woman's Shadow: Women's Costume of the Bronze Age as a "Text" (based on materials from the necropolises of the South Trans-Urals and Kazakhstan)). Chelyabinsk: "AvtoGraf” Publ. (in Russian).

13. Maksimova, A. G. 1961. In: Novye materialy po arheologii i ehtnografiyi Kazahstana (New materials on archeology and ethnography of Kazakhstan), 12. Alma-Ata: AN KazSSR Publ., 62-71 (in Russian). 
14. Margulan, A. Kh., Akishev, K. A., Kadyrbayev, M. K., Orazbayev, A. M. 1966. Drevnyaya kultura Centralnogo Kazahstana (Ancient Culture of Central Kazakhstan). AlmaAta: "Nauka" Publ. (in Russian).

15. Maryashev, A. N., Goryachev, A. A. 1993. In: Rossiyskaya arheologiya (Russian archeology), 1, 5-19 (in Russian).

16. Potemkina, T. M. 1985. Bronzovyi vek lesostepnogo Pritoboliya (Bronze age forest-steppe Tobol region). Moscow: "Nauka" Publ. (in Russian).

17. Rogozhinskiy, A. E. 1999. In: Istoriya i arheologiya Semirechiya (History and archaeology of Semrechie), 7-43 (in Russian).

18. Usmanova, E. R. 2010. Kostyum zhenshchiny epohi bronzy Kazahstana (Costume of a Woman of the Bronze Era of Kazakhstan). Karaganda: "TAiS” Publ. (in Russian).

19. Usmanova, E. R., Logvin, V.N. 1998. Zhenskie nakosnye ukrasheniya Kazakhstana: (epoha bronzy) (Women's skew jewelry of Kazakhstan: (Bronze Age)). Karaganda-Lisakovsk: E.A. Buketov Karagandy State University; Kostanay State University Publ. (in Russian).

20. Chernikov, S. S. 1960. Vostochnyi Kazakhstan v epohu bronzy / Materialy $i$ issledovaniya po arheologii SSSR (East Kazakhstan in the Bronze Age / Materials and research on the archeology of the USSR), 88. Moscow-Leningrad: USSR Academy of Sciences Publ. (in Russian).

\footnotetext{
Мүдделер қақтығысы туралы ақпаратты ашу. Авторлар мүдделер қақтығысының жоқтығын мәлімдейді. / Раскрытие информации о конфликте интересов. Авторы заявляют об отсутствии конфликта интересов. / Disclosure of conflict of interest information. The authors claims no conflict of interest.

Мақала туралы ақпарат / Информация о статье / Information about the article.

Редакцияға түсті / Поступила в редакцию / Entered the editorial office: 05.01.2021.

Рецензенттер мақұлдаған / Одобрено рецензентами / Approved by reviewers: 19.01.2021.

Жариялауға қабылданды / Принята к публикации / Accepted for publication: 02.02.2021.
} 